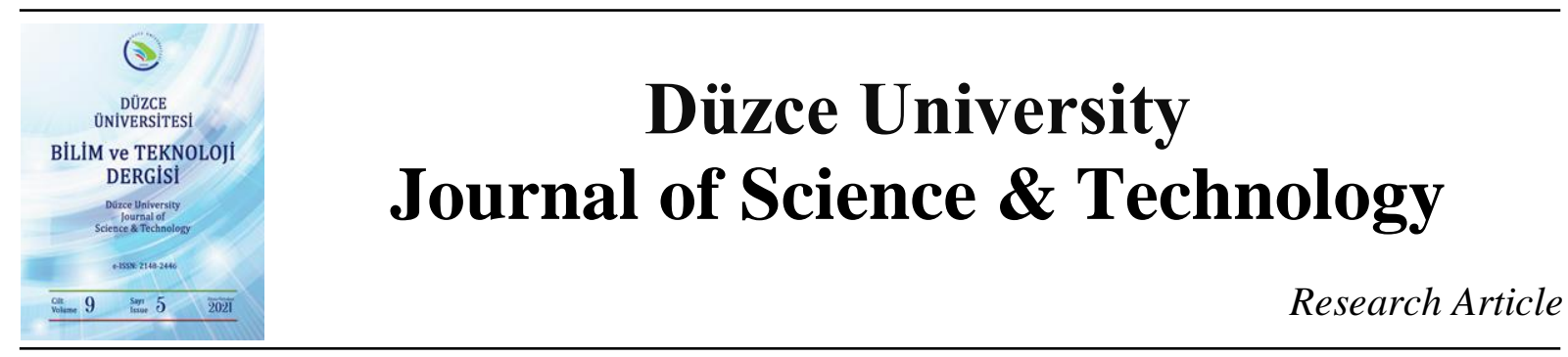

\title{
Ideal location selection for new stone crusher machine and landfill using FAHP and TOPSIS methods: a case study in a copper mine
}

\author{
Nima MIRZAEI ${ }^{\text {a,*, (D) Özlem Müge TESTIK }}{ }^{\mathrm{b}}$ \\ ${ }^{a}$ Department of Industrial Engineering, Faculty of Engineering, İstanbul Aydin University, İstanbul, TURKEY \\ ${ }^{b}$ Department of Industrial Engineering, Faculty of Engineering, Hacettepe University, Ankara, TURKEY \\ * Corresponding author's e-mail address: nimamirzaei@aydin.edu.tr
}

DOI: $10.29130 /$ dubited. 821490

\begin{abstract}
This study presents a practical approach used to find the best location for installing a new stone crusher machine and the landfill (waste) in the Sarcheshmeh copper in-pit mine located in the southeast of Iran. Fuzzy analytical hierarchal process (FAHP) and technique for order preference by similarity to ideal solution (TOPSIS) are the two methods, which applied in the study as a part of multi-criteria decision making (MCDM) analysis. In the first part FAHP method was utilized to find the ideal location for the stone crusher machine, and in the next part TOPSIS (in combination with Shannon entropy weighting) was used in landfill selection. The analysis was performed using the data collected from experts (engineers, mine specialists, and managers). The North, South, East, and West sides of the mine were considered as potential alternatives, and 21 factors were considered as criteria for computational analysis. The obtained results from FAHP suggested that the best alternative was alternative 3 (East side of the mine) to place the new stone crusher machine. Considering solid waste management, the TOPSIS method demonstrated that alternative 1 (North side of the mine) was the best location to be considered for landfills. Finally, a sensitivity analysis was carried out to examine the effects of changes in weights of criteria on the obtained results.
\end{abstract}

Keywords: Multi-criteria decision making, Shannon entropy, fuzzy analytical hierarchy process (FAHP), location decision technique for order preference by similarity to ideal solution (TOPSIS).

\section{FAHP ve TOPSIS kullanılarak yeni taş kırma makinesi ve katı atık sahası için en iyi yerin seçilmesi: bir bakır madeni örneği}

\begin{abstract}
ÖZ
Bu çalışma, İran'ın güneydoğusundaki Sarcheshmeh bakır çukur madeni için yeni bir taş kırma makinesinin ve katı atık sahasının (atık) yeri hakkında karar vermek için pratik bir yaklaşım sunmaktadır. Bu çalışmada, Bulanık analitik hiyerarşik Prosesi (FAHP) ve technique for order preference by similarity to ideal solution (TOPSIS), çok kriterli karar verme (MCDM) analizinin bir parçası olarak kullanılan iki yöntemdir. Birinci bölümde taş kırma makinesi için en uygun yeri bulmak için FAHP yöntemi kullanılmış, daha sonra depolama alanı seçimi için TOPSIS (Shannon entropi ağıllıklandırması ile birlikte) kullanılmıștır. Analiz, uzmanlar (mühendisler, maden mütehassıslar ve yöneticiler) toplanan verilere dayanılarak yapılmıștır. Madenin kuzey, güney, doğu ve batı tarafi potansiyel alternatifler olarak kabul edilmiş ve hesaplamalar için 21 faktör kriter olarak kabul edilmiștir. FAHP'den elde edilen sonuçlar, yeni taş kırma makinesinin yerleştirilmesi için en iyi alternatifin alternatif 3 (madenin doğu tarafi) olmasını önermiștir. Katı atık yönetimi dikkate alındığında ise TOPSIS yöntemi, alternatif 1 'in (madenin kuzey tarafi) düzenli depolama alanları için en iyi yer olduğunu göstermiștir. Son olarak, kriterlerin ağırlıkları değiştirildiğinde sonuçların nasıl değişeceğini incelemek için bir duyarlılık analizi yapıllmıştır.
\end{abstract}

Anahtar Kelimeler: Çok kriterli karar verme, Shannon entropy, bulanık analitik hiyerarşi Prosesi (FAHP), konum kararı, ideal çözüme benzerliğe göre sipariş tercihi tekniği (TOPSIS). 


\section{INTRODUCTION}

One of the major factors in mining engineering is the method that is used for evaluating different location alternatives. Generally, steps of a mining project endanger the environment's original condition, therefore, it is crucial to implement a suitable approach during the planning stage [1]. One of the steps in the planning stage is location decisions. Choosing a location requires long-term capital commitment and has an important effect on the operation procedures performance, and cost [2]. A selection of optimal location not only reduces fixed and variable costs for equipment installation and transportation but also increases operations and transportation speed. Location decision is the main issue for planning new development procedures [3]. It has different applications in different fields such as healthcare [4], power plants [5,6], distribution centers [7], and mining [8].

One of the common approaches for location decisions is multi criteria decision making (MCDM) method [9]. In another word, location selection is a classical MCDM problem. MCDM is the most long-familiar type of decision making [10]. Numerous scholars suggest MCDM as a suitable methodology to handle conflicting and both quantitative and qualitative objectives [11,12]. Three main steps of MCDM by the order are data processing, scheduling, and evaluation [13]. The planning procedure involves two methodologies, which are multi attribute decision-making (MADM) and multi objective decision making (MODM). In general, MCDM is classified into two classes: continuous and discrete MADM [14].

Famous researchers in the MCDM field utilized many different techniques. The most common techniques are analytical hierarchal process (AHP), the technique for order preference by similarity to ideal solution (TOPSIS), analytical network process (ANP), grey relational analysis (GRA), elimination and choice expressing reality (ELECTRE), linear programming technique, simple additive weighting (SAW), linear assignment method, conjunctive disjunctive method, maxi-max, and maxi-min [15]. These techniques have been applied for several application processes which have their characteristics in finding the ideal solution. For instance, in a study which was done by Lin and Tsai in 2010, MCDM was used to model location alternatives for the joint venture in new hospitals in China. They employed ANP to the proportional weighting of multiple rating criteria and then applied the TOPSIS method to rank 15 counties based on their overall performance [16]. Typically, the ELECTRE method is used when decision-makers' knowledge is vague and inaccurate [17]. In a study that faces such difficulty for plant location selection problems, researchers combined multi criteria intuitionistic fuzzy group decision making with the ELECTRE technique to find a suitable plant location [17]. Sometimes, combinations of two or more methods are used as a hybrid MCDM model for decision making and results seem to be preferable to those developed by a single MCDM method. Wang et. al in 2015 combined the SAW, TOPSIS, and GRA techniques to solve real-life MCDM problems and to select more accurate alternatives [18]. In another study performed by Shaverdi et al in 2016, they Combined Fuzzy TOPSIS and FAHP with financial ratios to design a novel performance assessment framework to rate the several organizations in the Iranian petrochemical industry [19]. Several researchers combined the Fuzzy technique with MDCM techniques (such as AHP and TOPSIS) for Group Decision Making Approach $[20,21]$.

As mentioned earlier, one of the popular MCDM techniques is the analytical hierarchical process (AHP) method. AHP was developed by Saaty in the late 1970s [22]. Later, in 2004, he developed the mathematical foundations by the independence of the important factors from the possible choices as in the AHP and also with dependence and feedback in the full decision making system as in the analytic network process (ANP)[23]. AHP method was applied in distinct areas such as warehouse site selection in production system [24], decision model for site location selection [25], global facility locationallocation problem [26], logistics of industrial location decisions [27], and warehouse location decision [28]. Besides, the technique was employed in different areas such as engineering, manufacturing, industry, politic, social, education, and management [29]. Often AHP techniques were used along with the geographical information system (GIS) technique for landfill (waste) site selection purposes [3032]. 
Another useful technique for location selection is TOPSIS. Hwang and Yoon originally developed it in 1980. Later the method was improved by Yoon in 1987, Hwang, Lia, and Liu in 1993 [33,34]. TOPSIS was utilized as a multi objective optimization approach for the location-allocation problem [35], pipe material selection in the sugar industry [36]. Optimal location selection of emergency operation centers [37], and to decide about the best location for Wastewater Treatment Solution [38]. Furthermore, from time to time it was combined with fuzzy techniques as an MCDM approach for location selection [39], [40].

In the Recent Times, scholars combined fuzzy logic with MCDM techniques to solve decision-making problems. For instance, Erdogan and Kaya in 2016 combined MCDM and fuzzy approach to decide the most beneficial area for a nuclear power plant in Turkey. First, they applied type II FAHP to find the weight unit of criteria, and then type II FTOPSIS was applied to determine the best alternative for the nuclear power plant location [5].

The remainder of this study is structured as follows: In Section 2, data collection and criteria evaluation was introduced. After that, the FAHP method and Integration of the Shannon Entropy and TOPSIS method were explained in the methodology section. Finally, computational results and future studies were discussed in section 4 .

\section{DATA COLLECTION AND CRITERIA EVALUATION}

\section{A. PROBLEM STATEMENT AND MOTIVATION}

In general, before the mining excavation project is started many experimental studies must be completed to predict the amount of ore deposit (in this study copper) that might be extracted from the mine. Nevertheless, the estimated outcomes of the experiments are based on probability theory. There are possible changes in the advent of variation to geology or sudden failure in the project. For that reason, investors are not willing to invest high capital at the beginning of excavation and drilling in a project.

This study was carried out in the Sarcheshmeh copper complex. It is one of the largest porphyry copper in the world. The mine is located southeastern of Iran, $65 \mathrm{~km}$ southwest of Kerman city, (Fig. 1.a)[41]. After few years the mining excavation started at the Sarcheshmeh copper complex, mining engineers find out that the amount of potential copper inside of the mine is much more than what they predicted. Therefore, the project manager decided to expand the mining excavation. Consequently, a new stone crusher machine is needed to speed up the utilization procedure, and the location for that stone crusher and its wase must be identified. This study aims to find the best location for the new stone crusher machine and landfill using FAHP and TOPSIS methods.

\section{B. POSSIBLE ALTERNATIVES AND CRITERIA SELECTION}

Because of the geometric shape of the Sarcheshmeh in-pit mine and save time and capital, the new stone crusher machine must be close to the sides of the mine. As it is depicted in Figure 1. (a), the top view of the mine is similar to the rectangle. After primary investigation and analysis were done by geomatic and civil engineers using the Geographical Information System (GIS) tool, they decided to select four locations as alternatives in this study. At the same time, because the mine surrounds a vast area, for safety reasons, and many other factors, accurate calculations and analysis need to be done to select an optimal location.

There are only 4 potential locations close to the mine that have enough space to install the new stone crusher machine. The approximate location of each of them is shown in Figure 1. (a) $\left(A_{1}\right.$ North, $A_{2}$ South, $\mathrm{A}_{3}$ East, and $\mathrm{A}_{4}$ West sides). In addition to the stone crusher machine, the waste of the machine must be collected and deposited close to the machine. To speed up the excavation and transportation procedures the possible alternatives are the north, south, east, and west side of the mine. Currently, there are three dumps placed on three different sides of the mine. Dump31 is located on the North side of the 
mine $\left(A_{1}\right)$, dump26 is located on the East side of the mine $\left(A_{3}\right)$, and dump15 is located on the West side of the mine $\left(\mathrm{A}_{4}\right)$. Also, it is possible to build a new dump on the South side of the mine $\left(\mathrm{A}_{2}\right)$. Therefore, there are four possible alternatives for landfill location selection.

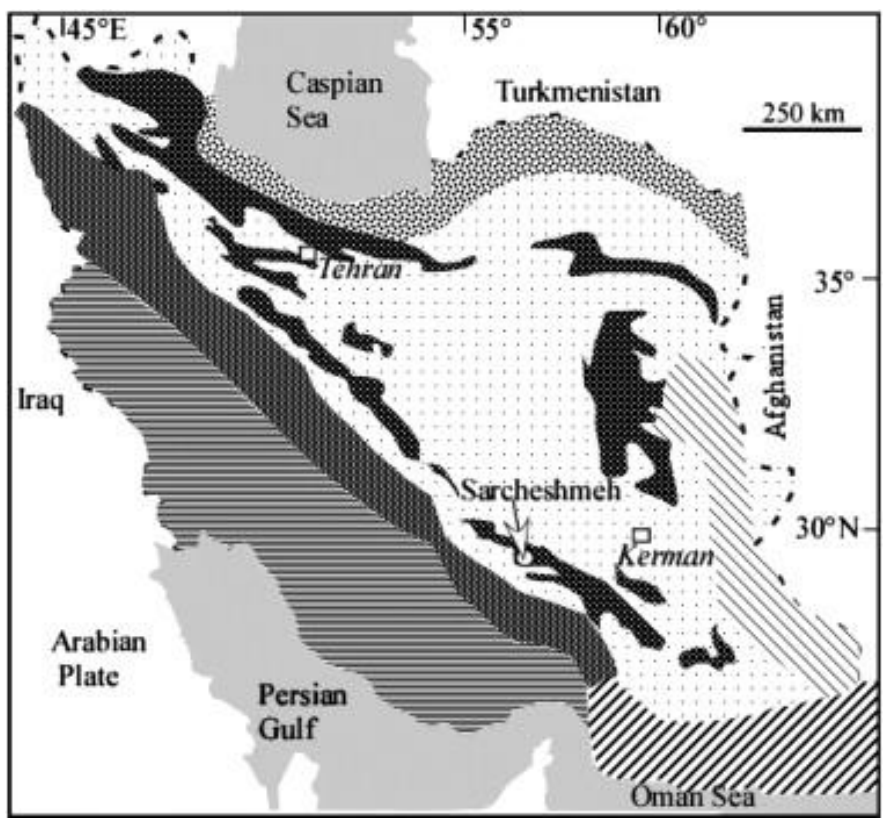

(a)

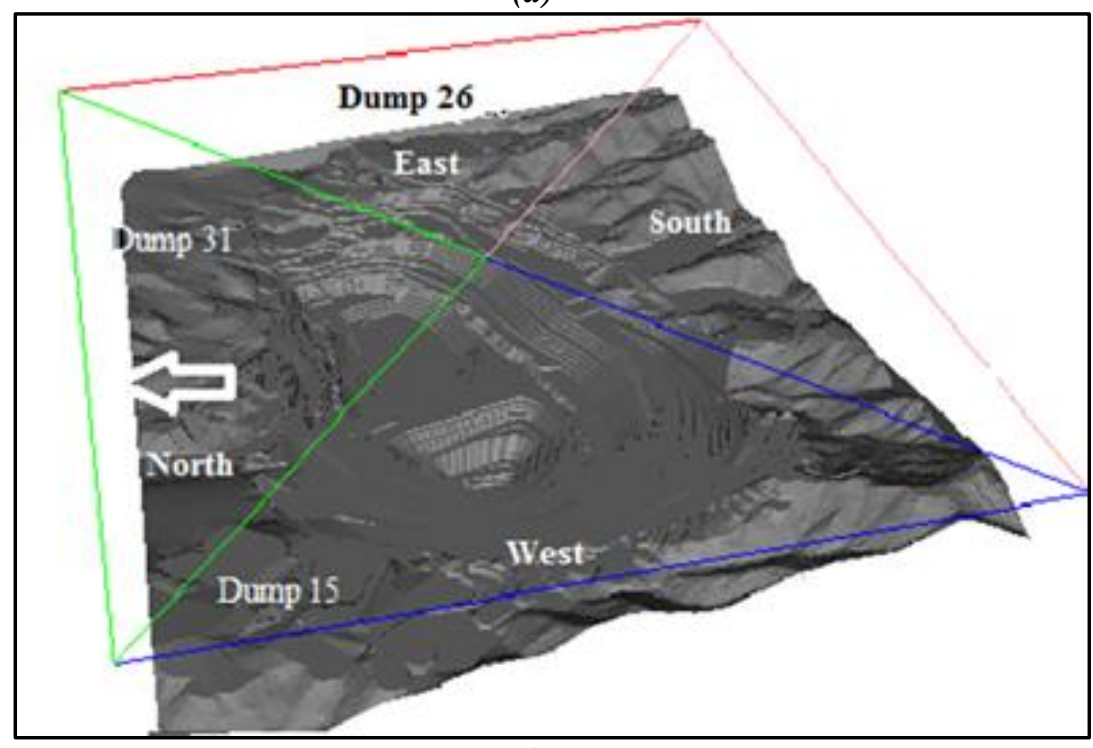

(b)

Figure 1. (a) Sarcheshmeh porphyry copper deposit[1]. (b) In-pit mine shape and locations of alternatives.

Criteria that were used to evaluate the alternatives were selected considering the recent literature and expert opinions. The list of experts with their careers, role position, field, and education are as follows:

- Two mine engineers, a specialist in mineral processing, exploration, and excavation, with a bachelor's degree in mining.

- One geologist, a specialist in environmental protection and education, with a bachelor's degree in geology.

- One civil engineer, a specialist in road and bridge construction, with a master's degree in civil engineering.

- One industrial engineering, a specialist in production and quality control, with a bachelor's degree in industrial engineering.

- One mechanical engineer, a specialist in metallurgy, with a bachelor's degree in mechanical engineering. 
- Project manager, a specialist in energy management, with a Ph.D. degree in management. The procedure of criteria selection are as follows:

First, each expert listed the parameters that appear to be important (according to his point of view) in the decision-making approach. Later, after several meetings and brainstorming the final parameters were selected. 4 main criteria were selected in the first phase. They were technical, economical, environmental, and geological. In the second phase, each main criterion was divided into several subcriteria. The most important and significant criteria were the ones that affected decision-making based on experts' analysis. Criteria included both quantitative and qualitative data that support the objective of the final location selected by the MCDM model.

Lastly, the AHP method was used to obtain the final weights of each criterion by applying a pairwise comparison. Before applying this critical step, experts rank each criterion according to Saaty's important scale (value from 1 to 9 ). A matrix was developed base on the geometric mean value of the expert opinions, that show the importance of each criterion compares to others. This process is done two times, once for the FAHP method and once for the TOPSIS method. Each criterion is divided into two indicators (index effect), positive and negative based on its characteristics. Moreover, each criterion has its weight considering the level of effect for location selection. The information regarding each criterion is summarized in Table 1. Besides, experts graded alternatives concerning each criterion from 1 to 9 (1 is the least score and 9 is the highest one).

Fig. 2 and 3 show the classification of the primary criteria and subcriteria. Four locations (as alternatives) are selected as potential spots where are located in the North, South, East, and West sides of sarcheshmeh mine. Fig.1(b) depicts the schematic structure of the Sarcheshmeh copper mine and alternatives locations. The plant layout of the mine and 4 alternative locations are illustrated in that figure.

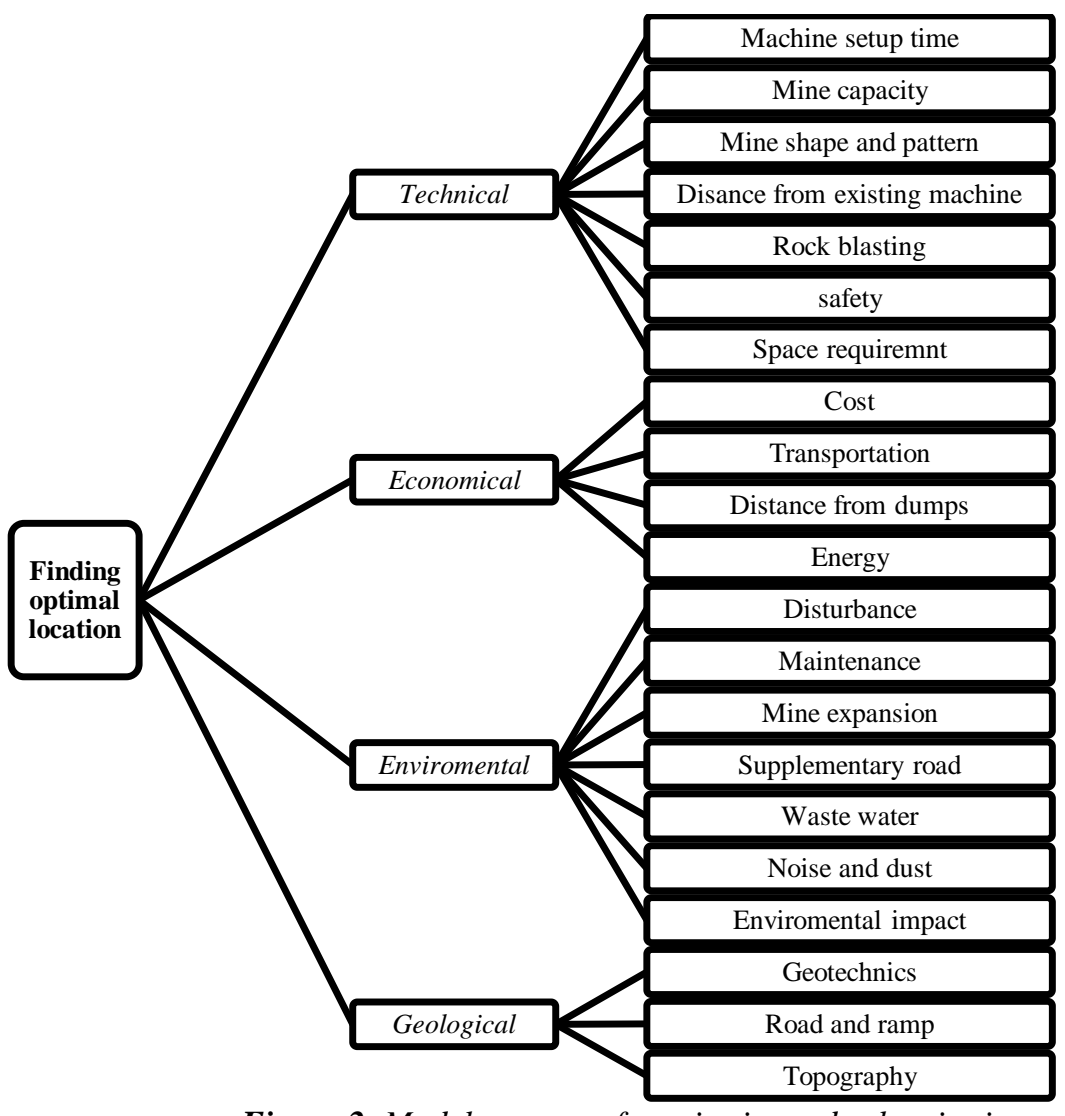

Figure 2. Model structure for criteria. and sub-criteria. 


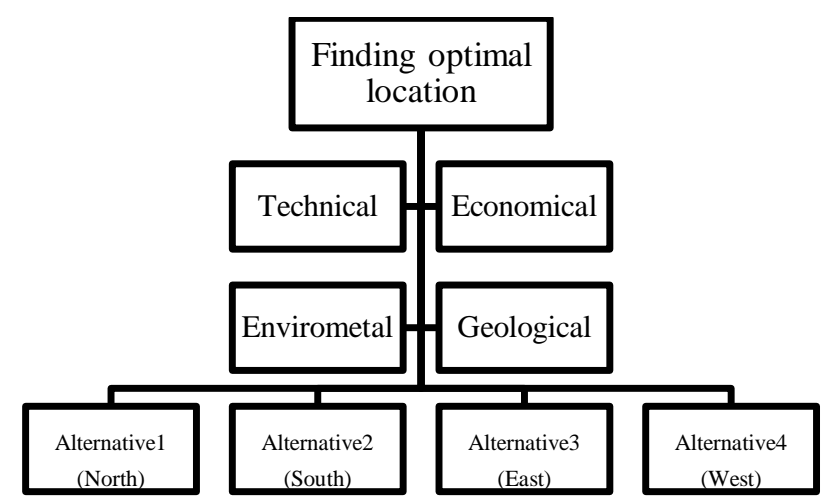

Figure 3. Main criteria and potential alternatives.

Table 1. Criteria weight and indicator.

\begin{tabular}{cccc}
\hline Criteria & Index effect & Criteria & Index effect \\
\hline Mine capacity & Positive & Space requirement & Positive \\
\hline Cost & Negative & Safety & Positive \\
\hline Geotechnics & Positive & Mine shape and pattern & Positive \\
\hline Transportation & Negative & Supplementary road & Positive \\
\hline Road and ramp & Positive & Distance from dumps & Positive \\
\hline Topography & Positive & Setup time & Negative \\
\hline Rock blasting & Negative & Mine expansion & Positive \\
\hline Energy & Positive & Wastewater & Negative \\
\hline Disturbance & Negative & Environmental impact & Negative \\
\hline Noise and dust & Negative & Distance From Existing & Positive \\
\hline Maintenance & Negative & machine &
\end{tabular}

\section{METHODOLOGY AND COMPUTATIONAL RESULTS}

This study represents the findings of an analysis, which is used two different MCDM techniques: Fuzzy AHP (FAHP) and TOPSIS to optimize the stone crusher machine and landfill location selection. In the first step, FAHP was used as a pairwise comparison to find the optimum location for the stone crusher. After extraction and crushing stone ore, the waste must be collected and deposited somewhere close to the mine. At this point, TOPSIS via a combination of Shannon Entropy weighting was utilized to find the best location for landfills and waste.

\section{A. FAHP METHOD}

Being a very well-known methodology, AHP is frequently used in cases where expert opinion guides the decision-makers in finding the optimal solution. Since the expert opinion are based on experts' professional experience or their subjective judgments, they are assumed to be non-objective. In cases where subjective evaluations take place in the model, implementing fuzzy logic to the analysis can eliminate imprecision and ambiguity. Fuzzy logic also gives effective results where linguistic evaluations are used.

Fuzzy AHP (FAHP) was introduced in Laarhoven ve Pedrycz (1983)'s study, where triangular fuzzy numbers are applied to the model to find fuzzy weights and to identify fuzzy evaluations [42]. Since the first attempts of FAHP, the methodology has been frequently used in many areas. Mardani et al. (2015) present a literature survey on fuzzy MCDM, where they stated that FAHP has been used more than other decision-making algorithms within two decades [43]. More detailed fuzzy MCDM and FAHP applications can be found in Mardani et al. (2015) [43].

Apart from other applications of FAHP, location selection problems are using FAHP in achieving a reasonable solution. Carlsson and Walden (1995) used FAHP in determining the optimal location of a 
new ice-hockey arena in Finland [44]. Chou et al. (2008) determined the optimal location for international tourist hotels in Taiwan by using FAHP [44]. Kuo et al. (2002) proposed a decision making model for selecting convenience store locations by combining FAHP and ANP [45]. In the study, weights of evaluations are calculated by FAHP. In a work by Ka (2011), FAHP and ELECTRE are used in defining a scientific location model of dry ports in China. In a case study from India [46], Choudhary and Shankar (2012) proposed FAHP to select the optimal location of the thermal power plant [47]. Ozgen and Gulsun (2014) integrated a two-phase possibilistic linear programming model by FAHP to find the optimal solution for multiple facility location selection problems [48]. One of the most recent studies is done by Du and Wang (2018), where the optimal location of monitoring sites is determined by FAHP and compared the results with AHP conclusions [49].

\section{A. 1. Location Selection By Using FAHP}

After determining the alternative locations for the problem, each alternative should be evaluated under each sub-criteria. During this process, experts' opinions are taken into consideration. Since experts' opinions are affected by their professional experiences or personal assessments, the evaluations are considered subjective judgments. Apart from this, in some cases, the evaluations may be done by linguistic scales. The imprecision that occurred in such cases may be eliminated by fuzzy logic. Although fuzzy logic does not aim to find an optimal solution, it may lead to noteworthy solutions. FAHP method used in this study is proposed by Chang in 1996, where pairwise comparisons are converted to triangular fuzzy numbers, because of their simplicity and linearity [50]. As the initial step, the scale used in pairwise comparison to identify the most important criteria is fuzzified. Likewise, the reciprocal of each evaluation is fuzzified, as given in Table 2.

Table 2. 1-9 FAHP Scale for pairwise comparison.

\begin{tabular}{cccc}
\hline Importance of i Relative to j & $\begin{array}{c}\text { Crisp } \\
\text { value }\end{array}$ & $\begin{array}{c}\text { Triangular } \\
\text { fuzzy scale }\end{array}$ & $\begin{array}{c}\text { Triangular fuzzy } \\
\text { reciprocal scale }\end{array}$ \\
\hline \multirow{2}{*}{ Equally important } & 1 & $(1,1,1)$ & $(1,1,1)$ \\
\cline { 2 - 4 } Slightly more important & 2 & $(1 / 2,3 / 4,1)$ & $(1,4 / 3,2)$ \\
\cline { 2 - 4 } Moderately more important & 3 & $(2 / 3,1,3 / 2)$ & $(2 / 3,1,3 / 2)$ \\
\cline { 2 - 4 } & 4 & $(1,3 / 2,2)$ & $(1 / 2,2 / 3,1)$ \\
\hline \multirow{2}{*}{ More important } & 5 & $(3 / 2,2,5 / 2)$ & $(2 / 5,1 / 2,2 / 3)$ \\
\hline Most important & 6 & $(2,5 / 2,3)$ & $(1 / 3,2 / 5,1 / 2)$ \\
\hline & 7 & $(5 / 2,3,7 / 2)$ & $(2 / 7,1 / 3,2 / 5)$ \\
\hline & 9 & $(3,7 / 2,4)$ & $(1 / 4,2 / 7,1 / 3)$ \\
\hline
\end{tabular}

In the first step of the fuzzy analysis, a fuzzy set (e.g. fuzzy set A) is set with its membership function $(\mu \mathrm{A}(\mathrm{x}))$, to demonstrate the level of possibility of fuzzy number $\mathrm{x}$, which represents its belonging to set A. The membership function of a triangular fuzzy number $\mathrm{x}$ is specified with upper, mean, and lower values of $\mathrm{x}$, introduced respectively as $(u, m, l)$.

$$
\mu_{A}(x)=\left\{\begin{array}{c}
\frac{(x-l)}{(m-l)}, l \leq x \leq m \\
\frac{(u-x)}{(u-m)}, m \leq x \leq u \\
0, \text { otherwise }
\end{array}\right.
$$

Chang's (1996) extent of the method, used in this research, is summed up as follows;

let $X=\left\{x_{1}, \ldots, x_{n}\right\}$ be the object set and $U=\left\{u_{1}, \ldots, u_{n}\right\}$ be the objective (goal) set.

Considering each object $\left(\mathrm{g}_{\mathrm{i}}\right)$ and performing the level evaluation for each goal, $m$ extent analysis values, represented by, $\mathrm{Y}=1, \ldots, m$ and $\mathrm{i}=1, \ldots, n$ are defined. Note that $M_{g_{i}}^{y}$ be a triangular fuzzy number, for all 
members that are demonstrated below. Chang's extent analysis relies on fuzzy synthetic $\left(\mathrm{S}_{\mathrm{i}}\right)$ values as given below:

$S_{i}=\sum_{j=1}^{m} M_{g_{i}}^{j} \otimes\left[\sum_{i=1}^{n} \sum_{j=1}^{m} M_{g_{i}}^{j}\right)^{-1}$

The value of $\sum_{j=1}^{m} M_{g_{i}}^{J}$ is computed with using fuzzy arithmetical calculations, as below;

$$
\sum_{j=1}^{m} \boldsymbol{M}_{g_{i}}^{J}=\left(\sum_{j=1}^{m} l_{j}, \sum_{j=1}^{m} m_{j}, \sum_{j=1}^{m} u_{j}\right)
$$

Next, in order to calculate the value of $\left[\sum_{i=1}^{n} \sum_{j=1}^{m} M_{g_{i}}^{j}\right)^{1}$, Equation (3) is calculated by using fuzzy arithmetic as;

$$
\sum_{i=1}^{n} \sum_{j=1}^{m} M_{g_{i}}^{j}=\left(\sum_{i=1}^{n} l_{i}, \sum_{i=1}^{n} m_{i}, \sum_{i=1}^{n} u_{i}\right)
$$

Calculating the inverse vector is the next step,

$$
\left[\sum_{i=1}^{n} \sum_{j=1}^{m} M_{g_{i}}^{j}\right]^{1}=\left(\frac{1}{\sum_{i=1}^{n} u_{i}}, \frac{1}{\sum_{i=1}^{n} m_{i}}, \frac{1}{\sum_{i=1}^{n} l_{i}}\right)
$$

For $j=1, \ldots, n$ and $i \neq j$, the level of possibility of $M_{1}=\left(l_{1}, m_{1}, u_{1}\right) \geq M_{2}=\left(l_{2}, m_{2}, u_{2}\right)$ is computed as,

$$
V\left(M_{2} \geq M_{1}\right)=\left\{\begin{array}{cl}
1, & m_{2} \\
0, & m_{1} \\
\frac{l_{1}-u_{2}}{\left(m_{2}-u_{2}\right)-\left(m_{1}-l_{1}\right)}, & \text { otherwise }
\end{array}\right.
$$

let $d^{\prime}\left(A_{i}\right)=\min V\left(S_{I} \geq S_{j}\right)$. where;

$$
\begin{aligned}
& V\left(M \geq M_{1}, M_{2}, \ldots, M_{K}\right)= \\
& \left.V\left[M \geq M_{1}\right) \text { and }\left(M \geq M_{2}\right) \text { and } \ldots \text { and }\left(M \geq M_{K}\right)\right]
\end{aligned}
$$

$=\min V\left(M \geq M_{i}\right), i=1,2,3, \ldots, k$.

And the normalized vector is $\mathrm{W}^{`}=\left(\mathrm{d}^{\top}\left(\mathrm{A}_{1}\right), \mathrm{d}^{\top}\left(\mathrm{A}_{2}\right), \ldots, \mathrm{d}^{\top}\left(\mathrm{A}_{\mathrm{n}}\right)\right)^{\mathrm{T}}$

Depending on the experts' evaluations, the matrices for fuzzy pairwise comparison are calculated in Appendix 1. For each criterion, alternatives are evaluated by experts and fuzzy assessments are achieved. Table 3 presents the results of crisp (non-fuzzy) weights for alternatives under each criterion, and weights of criteria. 
Table 3. criteria weights concerning each alternative and weights of criteria.

\begin{tabular}{cccccc}
\hline Criteria & $\mathbf{A}_{\mathbf{1}}$ & $\mathbf{A}_{\mathbf{2}}$ & $\mathbf{A}_{\mathbf{3}}$ & $\mathbf{A}_{\mathbf{4}}$ & Weight \\
\hline $\mathrm{C}_{1}$ & 0.926 & 0.000 & 0.074 & 0.000 & 0.162 \\
\hline $\mathrm{C}_{2}$ & 0.258 & 0.249 & 0.245 & 0.249 & 0.188 \\
\hline $\mathrm{C}_{3}$ & 0.250 & 0.250 & 0.25 & 0.250 & 0.099 \\
\hline $\mathrm{C}_{4}$ & 0.00 & 0.149 & 0.516 & 0.335 & 0.147 \\
\hline $\mathrm{C}_{5}$ & 0.250 & 0.250 & 0.25 & 0.25 & 0.140 \\
\hline $\mathrm{C}_{6}$ & 0.160 & 0.259 & 0.267 & 0.313 & 0.118 \\
\hline $\mathrm{C}_{7}$ & 0.000 & 0.289 & 0.435 & 0.276 & 0.147 \\
\hline $\mathrm{C}_{8}$ & 0.760 & 0.240 & 0.000 & 0.000 & 0.290 \\
\hline $\mathrm{C}_{9}$ & 0.439 & 0.282 & 0.155 & 0.123 & 0.258 \\
\hline $\mathrm{C}_{10}$ & 0.000 & 0.000 & 0.604 & 0.396 & 0.258 \\
\hline $\mathrm{C}_{11}$ & 0.250 & 0.250 & 0.250 & 0.250 & 0.194 \\
\hline $\mathrm{C}_{12}$ & 0.295 & 0.25 & 0.205 & 0.250 & 0.125 \\
\hline $\mathrm{C}_{13}$ & 0.318 & 0.294 & 0.199 & 0.189 & 0.256 \\
\hline $\mathrm{C}_{14}$ & 0.020 & 0.195 & 0.604 & 0.181 & 0.308 \\
\hline $\mathrm{C}_{15}$ & 0.295 & 0.250 & 0.205 & 0.250 & 0.125 \\
\hline $\mathrm{C}_{16}$ & 0.225 & 0.278 & 0.273 & 0.225 & 0.059 \\
\hline $\mathrm{C}_{17}$ & 0.250 & 0.250 & 0.25 & 0.250 & 0.059 \\
\hline $\mathrm{C}_{18}$ & 0.421 & 0.193 & 0.193 & 0.193 & 0.067 \\
\hline $\mathrm{C}_{19}$ & 0.421 & 0.193 & 0.193 & 0.193 & 0.184 \\
\hline $\mathrm{C}_{20}$ & 0.001 & 0.147 & 0.516 & 0.335 & 0.408 \\
\hline $\mathrm{C}_{21}$ & 0.255 & 0.255 & 0.236 & 0.255 & 0.408
\end{tabular}

Table 4. Final scores for alternatives.

\begin{tabular}{cc}
\hline Alternative & Score \\
\hline $\mathrm{A}_{1}$ & 0.2647 \\
\hline $\mathrm{A}_{2}$ & 0.2084 \\
\hline $\mathrm{A}_{3}$ & 0.3019 \\
\hline $\mathrm{A}_{4}$ & 0.2249 \\
\hline
\end{tabular}

At the final step, scores for four alternatives are calculated and the results are given in Table 4. In accordance with the outcome, alternative 3 has the highest score, where alternative 1 is placed in the second order.

\section{A. 1. Sensitivity analysis of FAHP method}

Sensitivity analysis for fuzzy AHP is conducted by creating different scenarios. In the first scenario (S1), the weights for all criteria are assumed as equal (1/21 each) and the results are compared with the first results. As seen in S1 column of Table 5, the order of alternatives is same as the first results. In the next scenario (S2), only the criteria with the highest weights $\left(\mathrm{C}_{20}\right.$ and $\left.\mathrm{C}_{21}\right)$ are considered. The weights of $\mathrm{C}_{20}$ and $\mathrm{C}_{21}$ are assumed be 0.5 each and the rest are assumed as zero. S2 column of Table 5 presents the results, where it can be seen that the scenario did not alter the best alternative. In the third scenario (S3), the criteria with the lowest weights $\left(\mathrm{C}_{16}\right.$ and $\left.\mathrm{C}_{17}\right)$ are excludes and the remaining criteria are weighted equally. The results are given in $\mathrm{S} 3$ column of Table 5, where alternative 3 is once again placed in the first order. In the fourth scenario (S4), 21 criteria are grouped in equally weighted four classes 
and it is assumed that the criteria in each group are also of equal weight. Results are presented in S4 column of Table 5 where it can be seen that the best alternative did not alter and the ranking of criteria is very similar to previous scenarios. Since changes in weights did not influence the best alternative, fuzzy AHP can be robustly used in cases of uncertainty.

Table 5. Sensitivity analysis for fuzzy AHP.

\begin{tabular}{ccccc}
\hline Alternative & S1 & S2 & S3 & S4 \\
\hline $\mathrm{A}_{1}$ & 0.2759 & 0.1279 & 0.2799 & 0.2780 \\
\hline $\mathrm{A}_{2}$ & 0.2154 & 0.2009 & 0.2103 & 0.2105 \\
\hline $\mathrm{A}_{3}$ & 0.2819 & 0.3758 & 0.2840 & 0.2834 \\
\hline $\mathrm{A}_{4}$ & 0.2268 & 0.2949 & 0.2257 & 0.2280 \\
\hline
\end{tabular}

\section{A. 2. Integration Of Shannon Entropy And TOPSIS Method}

In this section, an extension of the TOPSIS approach that integrates objective and subjective weight was proposed for final weight calculations. Therefore, it not only benefits decision-makers but also it is possible to consider other subjective factors into the decision-making process. In this innovative approach, the final weight will be more accurate, and it is up to the weighted average of experts and Shannon Entropy weights.

The Shannon Entropy method was introduced by Shannon in 1948, the method can be presented as follows [2]:

S.1: Creating a decision-making matrix $D$, which consists of $M$ choices $\left(A_{i}\right.$ for $\left.i=1, \ldots, M\right)$ and $N$ criteria $\left(C_{j}\right.$ for $\left.j=1, \ldots, N\right)$. The below matrix (equation 6$)$ is presented the decision matrix.

$$
D=\left[\begin{array}{ccc}
S_{11} & \ldots & s_{1 N} \\
\vdots & \ldots & \vdots \\
s_{M 1} & \ldots & S_{M N}
\end{array}\right]
$$

Which $\mathrm{d}_{\mathrm{ij}}$ is rating of choice $i$ in criterion $j$.

$S$. 2: In this step to determine the weights of Shannon Entropy, a normalized decision matrix is calculated for each criterion $C_{j}$.

$$
n_{i j}=\frac{s_{i j}}{\sqrt{\sum_{i}^{m} s_{i j}}}, i=1, \ldots, M, j=1, \ldots, N
$$

S. 3: Calculating entropy value $e_{j}$ as follows:

$$
e_{j}=-k \sum_{j=1}^{N} n_{i j} \ln \left(n_{i j}\right)
$$

where $k$ is a constant number and can be defined as $k=(\ln (m))^{-1}$.

$S .4: d_{j}$ is the degree of divergence of each criterion, which is equal to $1-e_{j}$. The higher $d_{j}$ indicates the more important criterion.

$S$. 5: The final weight for each criterion is computed as follows:

$$
w_{j}=\frac{d_{j}}{\sum_{k=1}^{N} d_{k}}
$$

After calculating the subjective weight of each criterion based on Shannon Entropy, it is possible to get a final weight for each criterion by integrating it to objective weights (decision-makers rating). The final weight is calculated by taking the average weight of objective and subjective weights. The final weight for each criterion was calculated based on the discussed steps before and they are written in appendix 2 (table A.1). Then the TOPSIS method was used for pair comparison between choices. 


\section{A.2.1. TOPSIS method}

TOPSIS method was introduced by Hwang and Yoon (1981) to solve MCDM problems. The method tries to find the best possible choices which are closest to the positive ideal solution and farthest from the negative ideal solution [3]. TOPSIS evaluating procedure was performed as follows:

$S$. 1: Developing the decision matrix $\mathrm{X}$ that rates each alternative concerning criteria. In matrix $\mathrm{X}, m$ shows the number of rows and $n$ represents the number of columns.

$$
X=\left[\begin{array}{ccc}
x_{11} & \ldots & x_{1 n} \\
\vdots & \ldots & \vdots \\
x_{m 1} & \ldots & x_{m n}
\end{array}\right]
$$

S. 2: Developing the normalized decision matrix R.

$$
R=\left[\begin{array}{ccc}
r_{11} & \cdots & r_{1 n} \\
\vdots & \ldots & \vdots \\
r_{m 1} & \ldots & v_{m n}
\end{array}\right] \quad r_{i j}=\frac{x_{i j}}{\sqrt{\sum_{i}^{m} x_{i j}^{2}}}
$$

where $r_{i j}$ denotes the normalized value for $i=(1, \ldots, m) ; j=(1, \ldots, n)$.

S. 3: Developing the weighted normalized decision matrix.

$$
W=\left[\begin{array}{lll}
w_{1} & \ldots & w_{m}
\end{array}\right] \quad V=W \times R=\left[\begin{array}{ccc}
v_{11} & \ldots & v_{1 n} \\
\vdots & \ldots & \vdots \\
v_{m 1} & \ldots & v_{m n}
\end{array}\right] . v_{i j}=w_{i j} \times r_{i j} \text { for } i=(1, \ldots, m) ; j=(1, \ldots, n)
$$

Where $w_{i j}$ is the weight of $j^{\text {th }}$ criterion.

S. 4: Negative and positive ideal solutions where calculated.

$$
A^{-}=\left\{v_{1}^{-} \ldots . v_{n}^{-}\right\} \quad A^{+}=\left\{v_{1}^{+} \ldots . v_{n}^{+}\right\}
$$

Where $\mathrm{A}^{-}$stands for the negative ideal solution, and $\mathrm{A}^{+}$stands for the positive ideal solution.

S. 5: Computing the distance from the positive ideal solution $\left(\mathrm{A}^{+}\right)$and negative ideal solution $\left(\mathrm{A}^{-}\right)$.

$$
D_{i}^{-}=\sqrt{\sum_{j=1}^{n}\left(v_{i j}-v_{j}^{-}\right)^{2}} \quad D_{i}^{+}=\sqrt{\sum_{j=1}^{n}\left(v_{i j}-v_{j}^{+}\right)^{2}} \quad i=1 . \ldots m
$$

Where $D_{i}^{+}$indicates the distance between the $\mathrm{i}^{\text {th }}$ alternative and the positive ideal solution, and $D_{i}^{-}$ indicates the distance between the negative ideal solution and the $i^{\text {th }}$ alternative.

$S$. 6: The $C_{i}$ that is relative closeness for each alternative was calculated and then the alternatives were ranked respectively.

$$
C_{i}=\frac{D_{i}^{-}}{D_{i}^{+}+D_{i}^{-}}
$$

Finally, an alternative, which had the highest relative closeness, was selected as the best alternative.

Table A.1 in Appendix 2 represents experts' evaluation scores for four alternatives for each criterion for landfill selection analysis, the matrix was constructed according to Table A.2 (normalized decision matrix) and Table A.3 (weighted normalized decision matrix) in the appendix. After calculating the positive and negative ideal solutions (see Table A.4 in Appendix 2), the distance from a negative ideal solution, the positive ideal solution, and the rank for each alternative were computed and illustrated in Table 6. Following the findings, it is possible to conclude that the best location for landfills is alternative 1 (dump 31) which is located on the north side of the Sarcheshmeh mine. 
Table 6. Landfill location selection.

\begin{tabular}{cccccc}
\hline $\mathbf{i}$ & $\boldsymbol{D}_{\boldsymbol{i}}^{+}$ & $\boldsymbol{D}_{\boldsymbol{i}}^{-}$ & Alternative & $\begin{array}{c}\text { Ranking } \\
\text { score }\end{array}$ & $\begin{array}{c}\text { Ranking } \\
\text { order }\end{array}$ \\
\hline 1 & 0.041 & 0.114 & $\mathrm{~A}_{1}$ & 0.805 & BEST \\
\hline 2 & 0.110 & 0.022 & $\mathrm{~A}_{2}$ & 0.168 & 4th \\
\hline 3 & 0.100 & 0.049 & $\mathrm{~A}_{3}$ & 0.330 & 2nd \\
\hline 4 & 0.109 & 0.050 & $\mathrm{~A}_{4}$ & 0.314 & 3rd \\
\hline
\end{tabular}

\section{A. 3. Sensitivity analysis of TOPSIS method}

Previous studies on sensitivity analysis of MCDM problems often focus on determining the most sensitive criteria or focused on finding the least value of change [53]. In this section, a new method for sensitivity analysis is considered that calculates the changing in the final score of alternatives when a change occurs in the weight of criteria. The following steps were used to find the new weight for the criteria [54].

S.1: Change the weight of criterion $\mathrm{k}\left(\mathrm{K}=1, \ldots, \mathrm{n}\right.$ and $\mathrm{n}=13$ in this study) from $\mathrm{W}_{\mathrm{k}}$ to $\mathrm{W}_{\mathrm{k}}^{*}$, namely, $\mathrm{W}_{\mathrm{k}}^{*}=\alpha \mathrm{W}_{\mathrm{k}}$, where $\alpha$ is the initial variation ratio of $\mathrm{W}_{\mathrm{k}}$ which is a positive number.

S.2: Compute the new weights of criteria $\mathrm{W}^{*}{ }_{1}, \mathrm{~W}^{*}{ }_{2}, \ldots, \mathrm{W}^{*}{ }_{\mathrm{n}}$ using the below formula:

$$
\left\{\begin{array}{c}
w_{1}^{*}=\frac{w_{1}}{w_{1}+w_{2}+\cdots+w_{k}^{*}+\cdots w_{n}} \\
w_{2}^{*}=\frac{w_{2}}{w_{1}+w_{2}+\cdots+w_{k}^{*}+\cdots w_{n}} \\
\cdot \\
w_{n}^{*}=\frac{w_{n}}{w_{1}+w_{2}+\cdots+w_{k}^{*}+\cdots w_{n}}
\end{array}\right.
$$

Finally, after computing all weights it is possible to find the score for each alternative. In this section, different scenarios were considered for the sensitivity analysis. The summary of sensitivity analysis was shown in Table 7. Different scenarios were considered to see how the order of alternative would be changed when the weight of criteria was manipulated. 
Table 7. Sensitivity analysis of TOPSIS technique.

\begin{tabular}{cccccccccc}
\hline Weights & & & \multicolumn{7}{c}{ Scenario } \\
& $\begin{array}{c}\text { Initial } \\
\text { weight }\end{array}$ & $\mathbf{1}$ & $\mathbf{2}$ & $\mathbf{3}^{*}$ & $\mathbf{4}^{*}$ & $\mathbf{5}$ & $\mathbf{6}$ & $\mathbf{7}$ & $\mathbf{8}$ \\
\hline $\mathrm{W}_{1}$ & 0.20 & 0.08 & $\mathbf{0 . 4 0}$ & 0.13 & 0.13 & 0.17 & 0.17 & $\mathbf{0 . 0 0}$ & 0.36 \\
\hline $\mathrm{W}_{2}$ & 0.15 & 0.08 & 0.11 & 0.10 & 0.10 & 0.13 & 0.13 & $\mathbf{0 . 0 0}$ & 0.27 \\
\hline $\mathrm{W}_{3}$ & 0.05 & 0.08 & 0.04 & 0.03 & 0.03 & 0.04 & 0.04 & 0.11 & $\mathbf{0 . 0 0}$ \\
\hline $\mathrm{W}_{4}$ & 0.05 & 0.08 & 0.04 & 0.03 & 0.03 & 0.04 & 0.04 & 0.11 & $\mathbf{0 . 0 0}$ \\
\hline $\mathrm{W}_{5}$ & 0.05 & 0.08 & 0.04 & 0.03 & 0.03 & 0.04 & 0.04 & 0.11 & $\mathbf{0 . 0 0}$ \\
\hline $\mathrm{W}_{6}$ & 0.05 & 0.08 & 0.04 & 0.03 & 0.03 & 0.04 & 0.04 & $\mathbf{0 . 0 0}$ & 0.09 \\
\hline $\mathrm{W}_{7}$ & 0.05 & 0.08 & 0.04 & 0.03 & 0.03 & 0.04 & 0.04 & $\mathbf{0 . 0 0}$ & 0.09 \\
\hline $\mathrm{W}_{8}$ & 0.05 & 0.08 & 0.04 & 0.03 & 0.03 & 0.04 & $\mathbf{0 . 2 0}$ & 0.11 & $\mathbf{0 . 0 0}$ \\
\hline $\mathrm{W}_{9}$ & 0.05 & 0.08 & 0.04 & 0.03 & 0.03 & 0.04 & 0.04 & 0.11 & $\mathbf{0 . 0 0}$ \\
\hline $\mathrm{W}_{10}$ & 0.10 & 0.08 & 0.07 & $\mathbf{0 . 4 0}$ & 0.07 & 0.08 & 0.08 & 0.22 & $\mathbf{0 . 0 0}$ \\
\hline $\mathrm{W}_{11}$ & 0.05 & 0.08 & 0.04 & 0.03 & 0.03 & 0.04 & 0.04 & $\mathbf{0 . 0 0}$ & 0.09 \\
\hline $\mathrm{W}_{12}$ & 0.05 & 0.08 & 0.04 & 0.03 & 0.03 & $\mathbf{0 . 2 0}$ & 0.04 & $\mathbf{0 . 0 0}$ & 0.09 \\
\hline $\mathrm{W}_{13}$ & 0.10 & 0.08 & 0.07 & 0.07 & $\mathbf{0 . 4 0}$ & 0.08 & 0.08 & 0.22 & $\mathbf{0 . 0 0}$ \\
\hline Alternative & & & & & & & & & \\
order & & & & & & & & & \\
\hline Best $^{\text {nd }}$ & $\mathrm{A}_{1=0.805}$ & $\mathrm{~A}_{1=0.716}$ & $\mathrm{~A}_{1=0.888}$ & $\mathbf{A}_{2=0.717}$ & $\mathbf{A}_{2=0.687}$ & $\mathrm{~A}_{1=0.805}$ & $\mathrm{~A}_{1=0.824}$ & $\mathrm{~A}_{1=0.670}$ & $\mathrm{~A}_{1=0.866}$ \\
\hline $\mathrm{A}_{3=0.330}$ & $\mathrm{~A}_{2=0.487}$ & $\mathrm{~A}_{2=0.226}$ & $\mathrm{~A}_{1=0.698}$ & $\mathrm{~A}_{1=0.588}$ & $\mathrm{~A}_{2=0.386}$ & $\mathrm{~A}_{2=0.348}$ & $\mathrm{~A}_{2=0.645}$ & $\mathrm{~A}_{2=0.236}$ \\
\hline $3^{\text {rd }}$ & $\mathrm{A}_{4=0.314}$ & $\mathrm{~A}_{4=0.418}$ & $\mathrm{~A}_{4=0.133}$ & $\mathrm{~A}_{4=0.308}$ & $\mathrm{~A}_{4=0.243}$ & $\mathrm{~A}_{4=0.231}$ & $\mathrm{~A}_{4=0.281}$ & $\mathrm{~A}_{4=0.442}$ & $\mathrm{~A}_{3=0.126}$ \\
\hline $4^{\text {th }}$ & $\mathrm{A}_{2=0.168}$ & $\mathrm{~A}_{3=0.290}$ & $\mathrm{~A}_{3=0.099}$ & $\mathrm{~A}_{3=0.083}$ & $\mathrm{~A}_{3=0.092}$ & $\mathrm{~A}_{3=0.176}$ & $\mathrm{~A}_{3=0.158}$ & $\mathrm{~A}_{3=0.257}$ & $\mathrm{~A}_{4=0.117}$ \\
\hline
\end{tabular}

In the first scenario, for convenience, the initial weights were assumed to be $1 / n$, where $n$ is the number of criteria selected for assessment $(n=13)$. As demonstrated in Table 7 best alternative was not changed but the order of the second, third and fourth alternatives was changed. In the second scenario, the weight of the first criterion $\left(\mathrm{C}_{1}\right.$, Cost) was increased from 0.1 to 0.4 to see how the result would be changed if cost becomes the most important criterion. The results showed that the score of the alternatives change however alternative 1 is still the best alternatives.

In the $3^{\text {rd }}$ and $4^{\text {th }}$ scenarios, the weight of criterion $10\left(\mathrm{C}_{10}\right.$, closeness to other machines $)$ and criterion 13 $\left(\mathrm{C}_{13}\right.$, closeness to existing dumps) were increased from 0.1 to 0.4 respectively. In both cases, the best alternatives changed and alternative 2 became the best alternatives.

In scenarios 5 and 6 , the weight of $\mathrm{C}_{8}$ (safety) and $\mathrm{C}_{12}$ (environmental effect) was increased from 0.05 to 0.2 . The result revealed that the best alternative is still $\mathrm{A}_{1}$.

To be more innovative, in scenarios 7 and 8 several criteria were eliminated to see how the result would be changed. In scenario 7 the criteria $\left(\mathrm{C}_{1}, \mathrm{C}_{2}, \mathrm{C}_{6}, \mathrm{C}_{7}, \mathrm{C}_{11}\right.$, and $\left.\mathrm{C}_{12}\right)$ that have a negative effect were eliminated and in scenario 8 the criteria $\left(\mathrm{C}_{3}, \mathrm{C}_{4}, \mathrm{C}_{5}, \mathrm{C}_{8}, \mathrm{C}_{9}, \mathrm{C}_{10}\right.$, and $\left.\mathrm{C}_{13}\right)$ that have a positive effect were eliminated. In both cases, the $\mathrm{A}_{1}$ remained the best alternative. After this analysis, it is possible to conclude that the result is sensitive to the weight of criteria 10 and 13 which are closeness to other machines and closeness to existing dumps. 


\section{CONCLUSION}

Location selection is an important issue in mining. An optimal location can improve productivity and minimize total cost. This study proposes a model to find the optimal locations for a stone crusher machine and landfill (waste) located in Sarcheshmeh mine in southern region of Iran. Because of the complexity of the problem, two MCDM methods (FAHP and Integration of Shannon Entropy And TOPSIS) were utilized. To perform the analysis, four main criteria (technical, economical, environmental and operational, and geological factors) and 21 sub-criteria were applied considering the literature review and expert judgments. 21 criteria were used in evaluating the given alternatives for stone crusher machine location selection, and 13 criteria were used for evaluating the alternatives for landfill selection. Geographical Information System (GIS) tool was used to choose four potential alternatives (North, South, East, and West sides of the mine) and it was done according to the primary investigation and analysis done by geomatic and civil engineers.

The methodology and computational analysis were separated into two main parts. In the first part, the FAHP technique was used to find the best location for the new stone crusher machine, and then, a sensitivity analysis was performed to examine the sensitivity of alternatives to the weights of each criterion. The analysis showed that alternative 3 (East side of the mine) has the highest score, while alternative 1 (North side of the mine) was placed in the second order. Sensitivity analysis for fuzzy AHP was conducted using four different scenarios. In each scenario, the weights of criteria were changed, however, the best alternative did not alter, and the ranking of criteria was very similar to previous scenarios. Since changes in weights did not influence the best alternative, fuzzy AHP can be robustly used in cases of uncertainty.

In the second part, the TOPSIS method in combination with Shannon entropy was used to find the best location for allocating stone crusher waste. After calculating the subjective weight of each criterion based on Shannon Entropy, the final weight was calculated by taking the average weight of objective (experts) and subjective weights. Following the findings, it was possible to conclude that the best location for landfills was alternative 1 (dump 31) which was located on the north side of the Sarcheshmeh mine. Lastly, a sensitivity analysis was considered to observe the changes in the final score of alternatives when a change occurred in the weight of criteria. 8 different scenarios were considered to see how the order of alternative would be changed when the weight of criteria was manipulated. In the $3^{\text {rd }}$ and $4^{\text {th }}$ scenarios, the weight of criterion $10\left(\mathrm{C}_{10}\right)$ and criterion $13\left(\mathrm{C}_{13}\right)$ were increased from 0.1 to 0.4 , respectively and in both cases, the best alternatives changed and alternative 2 (new dump) became the best alternatives. In other scenarios, the best alternative did not alter, and the ranking of criteria was very similar to each other. After this analysis, it was possible to conclude that the result was sensitive to the weight of criteria 10 and 13 (Closeness to other machines and existing dumps).

In future studies, the proposed model can be improved by adding more various criteria which affect the evaluation as well. In addition, different hybrid techniques such as fuzzy TOPSIS or other MCDM techniques (such as VIKOR, ANP, and PROMETHEE) can be considered for comparison of alternatives.

ACKNOWLEDGEMENTS: We would like to express our sincere thanks to industrial and mine engineers in Sarcheshmeh copper mine for the valuable information which helped us through the research.

\section{REFERENCES}

[1] I. Alavi, "Fuzzy AHP method for plant species selection in mine reclamation plans: Case study sungun copper mine," Iran. J. Fuzzy Syst., vol. 11, no. 5, pp. 23-38, 2014.

[2] M. Salles, "Decision making in SMEs and information requirements for competitive 
intelligence," Prod. Plan. Control, vol. 17, no. 3, pp. 229-237, 2006.

[3] İ. Ertuğrul and N. Karakaşoğlu, "Comparison of fuzzy AHP and fuzzy TOPSIS methods for facility location selection,” Int. J. Adv. Manuf. Technol., vol. 39, no. 7, pp. 783-795, 2008.

[4] A. Budak and A. Ustundag, "Fuzzy decision making model for selection of real time location systems," Appl. Soft Comput., vol. 36, pp. 177-184, 2015.

[5] M. Erdogan and I. Kaya, "A combined fuzzy approach to determine the best region for a nuclear power plant in Turkey,” Appl. Soft Comput. J., vol. 39, pp. 84-93, 2016.

[6] J. M. Sánchez-Lozano, M. S. García-Cascales, and M. T. Lamata, "Evaluation of suitable locations for the installation of solar thermoelectric power plants," Comput. Ind. Eng., vol. 87, pp. 343$355,2015$.

[7] R. Chakraborty, A. Ray, and P. K. Dan, "Multi criteria decision making methods for location selection of distribution centers," Int. J. Ind. Eng. Comput., vol. 4, no. 4, pp. 491-504, 2013.

[8] A. H. Bangian, M. Ataei, A. Sayadi, and A. Gholinejad, "Optimizing post-mining land use for pit area in open-pit mining using fuzzy decision making method," Int. J. Environ. Sci. Technol., vol. 9, no. 4, pp. 613-628, 2012.

[9] M. Erdoĝan and I. Kaya, "An integrated multi-criteria decision-making methodology based on type-2 fuzzy sets for selection among energy alternatives in Turkey," Iran. J. Fuzzy Syst., vol. 12, no. 1, pp. 1-25, 2015.

[10] A. Mardani, A. Jusoh, K. M. D. Nor, Z. Khalifah, N. Zakwan, and A. Valipour, "Multiple criteria decision-making techniques and their applications - A review of the literature from 2000 to 2014," Econ. Res. Istraz. , vol. 28, no. 1, pp. 516-571, 2015.

[11] D. Golmohammadi and M. Mellat-Parast, "Developing a grey-based decision-making model for supplier selection," Int. J. Prod. Econ., vol. 137, no. 2, pp. 191-200, 2012.

[12] C. Ram, G. Montibeller, and A. Morton, "Extending the use of scenario planning and MCDA for the evaluation of strategic options," J. Oper. Res. Soc., vol. 62, no. 5, pp. 817-829, 2011.

[13] G. T. Temur, "A novel multi attribute decision making approach for location decision under high uncertainty,” Appl. Soft Comput. J., vol. 40, pp. 674-682, 2016.

[14] E. K. Zavadskas, Z. Turskis, and S. Kildienè, "State of art surveys of overviews on MCDM/MADM methods," Technol. Econ. Dev. Econ., vol. 20, no. 1, pp. 165-179, 2014.

[15] R. Z. Farahani, M. SteadieSeifi, and N. Asgari, "Multiple criteria facility location problems: A survey," Appl. Math. Model., vol. 34, no. 7, pp. 1689-1709, 2010.

[16] C. T. Lin and M. C. Tsai, "Location choice for direct foreign investment in new hospitals in China by using ANP and TOPSIS," Qual. Quant., vol. 44, no. 2, pp. 375-390, 2010.

[17] K. Devi and S. P. Yadav, "A multicriteria intuitionistic fuzzy group decision making for plant location selection with ELECTRE method," Int. J. Adv. Manuf. Technol., vol. 66, no. 9-12, pp. 12191229, 2013.

[18] P. Wang, Z. Zhu, and Y. Wang, "A novel hybrid MCDM model combining the SAW, TOPSIS and GRA methods based on experimental design," Inf. Sci. (Ny)., vol. 345, pp. 27-45, 2016. 
[19] M. Shaverdi, I. Ramezani, R. Tahmasebi, and A. A. A. Rostamy, "Combining Fuzzy AHP and Fuzzy TOPSIS with Financial Ratios to Design a Novel Performance Evaluation Model," Int. J. Fuzzy Syst., vol. 18, no. 2, pp. 248-262, 2016.

[20] Z. Hussain and M. S. Yang, "Entropy for Hesitant Fuzzy Sets Based on Hausdorff Metric with Construction of Hesitant Fuzzy TOPSIS," Int. J. Fuzzy Syst., vol. 20, no. 8, pp. 2517-2533, 2018.

[21] F. Samanlioglu, Y. E. Taskaya, U. C. Gulen, and O. Cokcan, "A Fuzzy AHP-TOPSIS-Based Group Decision-Making Approach to IT Personnel Selection," Int. J. Fuzzy Syst., vol. 20, no. 5, pp. 1576-1591, 2018.

[22] Saaty T.L., The Analytic Hierarchy Process. New York: McGraw-Hill, 1980.

[23] T. L. Saaty, "Decision making — the Analytic Hierarchy and Network Processes (AHP/ANP)," J. Syst. Sci. Syst. Eng., vol. 13, no. 1, pp. 1-35, 2004.

[24] J. Korpela and M. Tuominen, "A decision aid in warehouse site selection," Int. J. Prod. Econ., vol. 45, no. 1-3, pp. 169-180, 1996.

[25] J. Yang and H. Lee, "An AHP decision model for facility location selection," Facilities, vol. 15, no. 9/10, pp. 241-254, 1997.

[26] M. A. Badri, "Combining the analytic hierarchy process and goal programming for global facility location-allocation problem," Int. J. Prod. Econ., vol. 62, no. 3, pp. 237-248, 1999.

[27] P. Alberto, "The Logistics of Industrial Location Decisions: An Application of the Analytic Hierarchy Process Methodology," Int. J. Logist. Res. Appl. A Lead. J. Supply Chain Manag., vol. 3, no. 3, pp. 273-289, 2000.

[28] S. Y. Roh, H. M. Jang, and C. H. Han, "Warehouse location decision factors in humanitarian relief logistics," Asian J. Shipp. Logist., vol. 29, no. 1, pp. 103-120, 2013.

[29] O. S. Vaidya and S. Kumar, "Analytic hierarchy process: An overview of applications," European Journal of Operational Research, vol. 169, no. 1. pp. 1-29, 2006.

[30] S. Önüt and S. Soner, "Transshipment site selection using the AHP and TOPSIS approaches under fuzzy environment," Waste Manag., vol. 28, no. 9, pp. 1552-1559, 2008.

[31] G. Wang, L. Qin, G. Li, and L. Chen, "Landfill site selection using spatial information technologies and AHP: A case study in Beijing, China," J. Environ. Manage., vol. 90, no. 8, pp. 2414$2421,2009$.

[32] P. V. Gorsevski, K. R. Donevska, C. D. Mitrovski, and J. P. Frizado, "Integrating multi-criteria evaluation techniques with geographic information systems for landfill site selection: A case study using ordered weighted average," Waste Manag., vol. 32, no. 2, pp. 287-296, 2012.

[33] K. Hwang, Ching-Lai, Yoon, Multiple Attribute Decision Making - Methods and Applications. A State-of-the-Art Survey. Springer Berlin Heidelberg, 1981.

[34] C.-L. Hwang, Y.-J. Lai, and T.-Y. Liu, "A new approach for multiple objective decision making," Comput. Oper. Res., vol. 20, no. 8, pp. 889-899, Oct. 1993.

[35] S. Beheshtifar and A. Alimoahmmadi, "A multiobjective optimization approach for locationallocation of clinics," Int. Trans. Oper. Res., vol. 22, no. 2, pp. 313-328, 2015. 
[36] L. Anojkumar, M. Ilangkumaran, and V. Sasirekha, "Comparative analysis of MCDM methods for pipe material selection in sugar industry," Expert Syst. Appl., vol. 41, no. 6, pp. 2964-2980, 2014.

[37] U. Di Matteo, P. M. Pezzimenti, and A. A. D, "Methodological proposal for optimal location of emergency operation centers through multi-criteria approach," Sustain., vol. 8, no. 1, pp. 1-12, 2016.

[38] P. P. Kalbar, S. Karmakar, and S. R. Asolekar, "Selection of an appropriate wastewater treatment technology: A scenario-based multiple-attribute decision-making approach," J. Environ. Manage., vol. 113, pp. 158-169, 2012.

[39] C. Rao, M. Goh, Y. Zhao, and J. Zheng, "Location selection of city logistics centers under sustainability," Transp. Res. Part D Transp. Environ., vol. 36, pp. 29-44, 2015.

[40] A. Awasthi, S. S. Chauhan, and S. K. Goyal, "A multi-criteria decision making approach for location planning for urban distribution centers under uncertainty," Math. Comput. Model., vol. 53, no. 1-2, pp. 98-109, 2011.

[41] M. Boomeri, K. Nakashima, and D. R. Lentz, "The Sarcheshmeh porphyry copper deposit, Kerman, Iran: A mineralogical analysis of the igneous rocks and alteration zones including halogen element systematics related to $\mathrm{Cu}$ mineralization processes," Ore Geol. Rev., vol. 38, no. 4, pp. 367$381,2010$.

[42] P. J. M. van Laarhoven and W. Pedrycz, "A fuzzy extension of Saaty's priority theory,” Fuzzy Sets Syst., vol. 11, no. 1-3, pp. 229-241, 1983.

[43] A. Mardani, A. Jusoh, and E. K. Zavadskas, "Fuzzy multiple criteria decision-making techniques and applications - Two decades review from 1994 to 2014," Expert Syst. Appl., vol. 42, no. 8, pp. 4126-4148, 2015.

[44] J. Yang and H. Lee, "Facilities An AHP decision model for facility location selection," Facil. Int. J. Oper. \&amp Prod. Manag. Iss, vol. 15, no. 22, pp. 241-254, 1997.

[45] R. J. Kuo, S. C. Chi, and S. S. Kao, "A decision support system for selecting convenience store location through integration of fuzzy AHP and artificial neural network," Comput. Ind., vol. 47, no. 2, pp. 199-214, 2002.

[46] B. Ka, "Application of Fuzzy AHP and ELECTRE to China Dry Port Location Selection," Asian J. Shipp. Logist., vol. 27, no. 2, pp. 331-353, 2011.

[47] D. Choudhary and R. Shankar, "An STEEP-fuzzy AHP-TOPSIS framework for evaluation and selection of thermal power plant location: A case study from India," Energy, vol. 42, no. 1, pp. 510 $521,2012$.

[48] D. Ozgen and B. Gulsun, "Combining possibilistic linear programming and fuzzy AHP for solving the multi-objective capacitated multi-facility location problem," Inf. Sci. (Ny)., vol. 268, pp. 185-201, 2014.

[49] X. Du and Z. Wang, "Optimizing monitoring locations using a combination of GIS and fuzzy multi criteria decision analysis, a case study from the Tomur World Natural Heritage site," J. Nat. Conserv., vol. 43, pp. 67-74, 2018.

[50] D.-Y. Chang, "Applications of the extent analysis method on fuzzy AHP," Eur. J. Oper. Res., vol. 95, no. 3, pp. 649-655, 1996.

[51] C. E. Shannon, “A Mathematical Theory of Communication,” Bell Syst. Tech. J., vol. 27, no. 4, 
pp. 623-656, 1948.

[52] C.-L. Hwang and K. Yoon, Multiple Attribute Decision Making, vol. 186. Berlin, Heidelberg: Springer Berlin Heidelberg, 1981.

[53] A. Amini and A. Alinezhad, "Sensitivity Analysis of TOPSIS Technique: The Results of Change in the Weight of One Attribute on the Final Ranking of Alternatives," J. Optim. Ind. Eng., vol. 7, no. 2011, pp. 23-28, 2011.

[54] P. Li, H. Qian, J. Wu, and J. Chen, "Sensitivity analysis of TOPSIS method in water quality assessment: I. Sensitivity to the parameter weights," Environ. Monit. Assess., vol. 185, no. 3, pp. 2453$2461,2013$. 